\title{
Pengaruh Polifenol Teh Hijau Terhadap \\ Produksi Tnf-A (Tumour Necrosis Factor-A) Pada \\ Kultur Sel Trofoblas Manusia Yang Dipapar Glukosa Tinggi 33 Mm
}

\author{
Siti Aisahı, Sasmito Djatiı, Husnul Khotimah2 \\ 1 Jurusan Biologi Fakultas Matematika dan Ilmu Pengetahuan Alam Universitas Brawijaya \\ 2 Fakultas Kedokteran, Universitas Brawijaya
}

\begin{abstract}
The purpose of this research was to study the effect of green tea polyphenol to TNF-á production on human trophoblast cell culture exposed by $33 \mathrm{mM}$ glucose. Trophoblast culture isolated from human fetal placental tissue by sectio caessaria. Monolayer trophoblast cells that had been incubated for 3 days at $5 \% \mathrm{CO} 2 ; 37^{\circ} \mathrm{C}$ were divided into 2 groups: (1) normal glucose ( $5 \mathrm{mM})$ and (2) glucose $33 \mathrm{mM}$ exposure, both divided into 2 sub groups: (a) without green tea polyphenol treatment, and (b) green tea polyphenol treatment 0,1; 0,2; and 0;4 $\mathrm{mg} / \mathrm{ml}$. Cells incubated for 3 days at $5 \% \mathrm{CO} ; 37^{\circ} \mathrm{C}$ then analyzed cytotrophoblast cells characteristic. TNF-á level was measured by ELISA and analyzed with oneway ANOVA. Immunocytochemistry showed the number of cells that expressed TNF-á then analyzed descriptively. The results of this study showed that TNF-á level at 0,1;0,2; and 0,4 $\mathrm{mg} / \mathrm{ml}$ polyphenol were 2804,333 $\tilde{n} \mathrm{~g} /$ $\mathrm{mL} ; 2513,222 \mathrm{ng} / \mathrm{ml}$; and 2739,889 $\tilde{\mathrm{ng}} / \mathrm{ml}$ respectively compared with 2739,889 $\tilde{\mathrm{ng}} / \mathrm{mL}$ normal

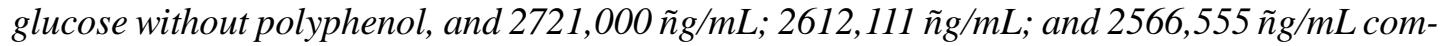
pared with 2621,000 $\tilde{\mathrm{ng}} / \mathrm{mL}$ glucose $33 \mathrm{mM}$ exposure without polyphenol. Number of cells that expressed TNF-á with 0,1;0,2; and 0,4 $\mathrm{mg} / \mathrm{ml}$ polyphenol treatment were $0 \% ; 2 \%$; and 5,5\% compared with $0 \%$ normal glucose without polyphenol, and $82 \%$; $0 \%$; and $0 \%$ compared with $3 \%$ glucose $33 \mathrm{mM}$ exposure without polyphenol. Green tea polyphenol exposure for 3 days at 0,1; 0,2; and 0,4 mg/ml didn't significantly affect the decreasing of TNF-á production.
\end{abstract}

Keywords: GDM, green tea, polyphenol, TNF-á, trophoblast

\section{Latar Belakang}

Penyakit diabetes mellitus pada kehamilan disebut GDM (Gestational Diabetes Mellitus) yang dikarakterisasikan dengan hiperglikemia (tingginya kadar glukosa dalam darah) serta abnormalitas biokimia yang menyertai pada kejadian diabebetes mellitus (DM) tipe-2 (Wolf, et al., 2002). Hasil penelitian Diabetes Control dan Complications Trial (DCCT) menunjukkan bahwa hiperglikemia merupakan faktor utama penyebab terjadinya diabetes dan perkembangan dari komplikasi vaskuler DM (Jakus, 2000). Hiperglikemia meningkatkan pembentukan radikal bebas melalui berbagai mekanisme, salah satunya adalah melalui pembentukan stres oksidatif. Hiperglikemia akut pada diabetes yang diinduksi stress oksidatif intraseluler, dikarakterisasikan dengan peningkatan kadar radikal bebas ROS (Reactive Oxygen Species) yang signifikan dan penurunan kemampuan antioksidan (Coughland, et al., 2004). Radikal bebas merupakan atom, molekul atau senyawa yang mempunyai elektron yang tidak berpasangan sehingga bersifat tidak stabil dan mempunyai reaktivitas yang tinggi (Wuryandari, 2002).

Reaktivitas radikal bebas dapat dihambat atau dihentikan oleh suatu substansi antioksidan sehingga dapat menghambat kerusakan oksidatif suatu molekul (Halliwel dan Gutteridge, 1998). Stres oksidatif terjadi jika terdapat peningkatan pembentukan radikal bebas dan penurunan kapasitas antioksidan endogen. Oleh karena itu dibutuhkan tambahan asupan antioksidan eksogen melalui berbagai sumber untuk mencegah terjadinya stres oksidatif. GDM merupakan kehamilan dengan intoleransi glukosa yang terjadi pada 1,9-3,6\% wanita hamil di Indonesia sedangkan komplikasinya terjadi sekitar 2- 
$4 \%$ di dunia. GDM secara signifikan menyebabkan fetal macrosomia (bayi berbadan besar), perinatal mortality (angka kematian bayi yang berusia kurang dari 28 hari), dan resiko maternal yang sama seperti pada diabetes tipe 2 (Coughland, et al., 2004). Sekitar 40-60\% wanita yang pernah mengalami GDM pada pengamatan lanjut pasca persalinan akan mengidap diabetes mellitus tipe 2 (Suparman, 2007). Pada kasus GDM, tingginya kadar glukosa dalam darah maternal akan ditranspor juga ke fetal melalui plasenta sehingga menyebabkan terjadinya gangguan metabolisme baik pada maternal maupun fetal. Gangguan metabolisme tersebut akan berimplikasi pada abnormalitas komposisi glukosa pada sirkulasi fetal yang memungkinkan terjadinya berbagai komplikasi pada fetal dan akan merangsang pertumbuhan yang berlebihan.

Produksi sitokin sebagai mediator inflamasi diduga berkaitan dengan pembentukan ROS yang berlebihan. Sitokin mempunyai peran penting dalam patofisiologi yang diekspresikan pada kondisi abnormal pada plasenta janin selama kehamilan. Regulasi sitokin dipengaruhi oleh stres oksidatif. TNF-á (Tumor Necrosis Factor-á) diproduksi oleh plasenta dan kemunculannya berhubungan dengan beberapa kejadian metabolik. Sitokin TNFá berpengaruh terhadap patogenesis pada diabetes tipe 2, tetapi sedikit data yang menyebutkan tentang pengaruh sitokin TNFá terhadap GDM yang memiliki abnormalitas biokimia yang sama dengan diabetes tipe 2 (Coughland, et al., 2004).

Berbagai terapi telah banyak dikembangkan untuk mengatasi gangguan GDM, termasuk diet, olahraga dan penggunaan berbagai macam terapi herbal. Penggunaan obat-obat penurun kadar glukosa oral tidak dianjurkan bagi wanita hamil menurut American Diabetes Association. Oleh karena itu, perlu dikaji salah satu bahan alam yang dapat dikembangkan sebagai terapi dalam mengatasi GDM yang terkait dengan stres oksidatif. Salah satu satu bahan alami tersebut adalah teh hijau dengan komponen aktif yang disebut polifenol. Polifenol pada teh hijau adalah flavonol dan catechin sedangkan komponen polifenol pada teh hitam adalah theaflavin dan theaburigin. Menurut Mc Kay dan Blumberg (2002) melaporkan bahwa kemampuan polifenol menangkap radikal bebas $100 \mathrm{kali}$ lebih efektif dibanding vitamin C dan 25 kali lebih efektif dari vitamin E. Selain itu, teh hijau memiliki komponen polifenol yang yang lebih banyak dibandingkan dengan teh hitam. Penelitian Yang, et al., (1998) menunjukkan peran teh hijau sebagai anti inflamasi, penghambatan pada NF-kB sehingga menurunkan pembentukan sitokin proinflamasi (TNF-á dan IL-1) pada macrophage cell line RAW264.7 dan makrofag peritoneal. Hal ini sesuai dengan laporan Ann dan Zigang (2003) yang menunjukkan bahwa EGCG mampu menghambat produksi hidrogen peroksida $(\mathrm{H} 2 \mathrm{O} 2)$ yang diinduksi oleh UVB pada normal human epidermal keratinocytes (NHEK). Polifenol EGCG pada teh hijau telah diketahui mampu melakukan penghambatan keradangan yang terkait dengan produksi sitokin. Pada penelitian ini, sel trofoblas yang merupakan sel epitel penyusun jaringan plasenta dipapar glukosa tinggi $33 \mathrm{mM}$ sebagai model kejadian eksperimental kondisi hiperglikemia pada kasus GDM. Dengan adanya keterlibatan stres oksidatif dalam patofisiologi GDM yang berimplikasi pada inflamasi, maka perlu dilakukan pemberian terapi polifenol teh hijau yang dilakukan bersamaan dengan paparan glukosa $33 \mathrm{mM}$ sehingga diharapkan dapat mencegah atau menghambat timbulnya komplikasi GDM. Perlakuan polifenol teh hijau sebagai antioksidan eksogen yang terkait dengan kondisi stres oksidatif pada kasus GDM diharapkan mampu menurunkan produksi sitokin TNF-á sehingga perlu dikaji secara in vitro pada kultur sel trofoblas dengan paparan polifenol teh hijau.

\section{Metode Penelitian \\ Waktu dan Tempat}

Penelitian ini dilakukan pada bulan Januari sampai bulan September 2008 di Laboratorium Reprogen Rumah Sakit Bersalin Mutiara Bunda, Ciujung, Malang; Laboratorium Sentral Biomedik, Fakultas Kedokteran Universitas Brawijaya, Malang; serta Laboratorium Fisiologi Hewan, Jurusan Biologi, Fakultas MIPA, Universitas Brawijaya, Malang. Jaringan plasenta normal melalui persalinan sectio caessarria diperoleh dari Rumah Sakit Bersalin Mutiara Bunda, Ciujung, Malang. 


\section{Prosedur Kerja \\ Isolasi dan Kultur Sel Trofoblas Plasenta}

Jaringan plasenta normal diperoleh dari Rumah Sakit Bersalin Mutiara Bunda, Ciujung, Malang dengan persalinan melalui operasi sectio caessaria. Disiapkan botol berisi larutan cord solution dari refrigerator (suhu $4{ }^{\circ} \mathrm{C}$ ). Segera setelah kelahiran, plasenta dipotong dan langsung dimasukkan ke dalam larutan cord solution. Metode isolasi dan kultur sel trofoblas dilakukan berdasarkan modifikasi dari metode isolasi secara enzimatik menurut Jones (1996). Sebelumnya bagian dasar plate kultur 6 well dilapisi cover glass dan ditetesi dengan $\pm 0,5$ $1 \mathrm{ml}$ gelatin $(0.2 \%)$ dan diinkubasi selama \pm 30-60 menit. Jaringan plasenta dicuci menggunakan PBS-A steril (PBS-A) pH 7,4 yang mengandung antibiotik pen-strep dalam cawan petri sampai terbebas dari darah. Jaringan dipotong-potong sampai kecil \pm 2 mm3 dan dibilas dengan PBSA steril pH 7,4 yang mengandung pen-strep, kemudian dipipetting dan disentrifugasi pada $2500 \mathrm{rpm}$ selama 10 menit. Supernatan dibuang dan pelet I diresuspensi dengan $5 \mathrm{~mL}$ medium kultur serum free (M-199 + penstrep), dipipetting dan disentrifugasi pada $2500 \mathrm{rpm}$ selama 10 menit. Supernatan dibuang dan pelet II diresuspensi dengan medium kultur yang mengandung serum (M-199 + pen-strep $+10 \%$ FBS $)$, diambil sebanyak $\pm 500 \mathrm{iL}$ potongan jaringan dimasukkan pada plate kultur 6 well dan diinkubasi pada inkubator CO2 5\%, suhu $37^{\circ} \mathrm{C}$ selama 30 menit. Ditambahkan 1,5 ml medium M-199 yang mengandung FBS $10 \%$ lalu diinkubasi pada inkubator $\mathrm{CO} 25 \%$, suhu $37^{\circ} \mathrm{C}$. Penggantian medium kultur dilakukan setelah 24 jam dengan M-199 + 10\% FBS kemudian ditumbuhkan kembali pada incubator $\mathrm{CO} 2$ $5 \%$, s uhu $37{ }^{\circ} \mathrm{C}$ selama 3 hari kemudian dipanen.

\section{Pembuatan Larutan Polifenol Teh Hijau}

Larutan stok polifenol teh hijau $(40 \mathrm{mg} / \mathrm{ml})$ dibuat dengan menggunakan serbuk polifenol teh hijau (Polyphenon 60 from Green Tea, Sigma). Dalam pembuatan larutan stok, konsentrasi etanol adalah $1 \%$. Pada dosis 0,4 diambil 20 il larutan stok ditambah $2 \mathrm{ml}$ medium, untuk mendapatkan dosis $0,2 \mathrm{mg} / \mathrm{ml}$ diambil 10 il larutan stok ditambah $2 \mathrm{ml}$ medium. Demikian juga untuk membuat dosis $0,1 \mathrm{mg} / \mathrm{ml}$, diambil 5 ìl larutan stok ditambah $2 \mathrm{ml}$ medium.

\section{Perlakuan Menggunakan Glukosa dan Polifenol Teh Hijau}

Perlakuan menggunakan glukosa didasarkan pada penelitian yang telah dilakukan oleh Khotimah (2003), dengan pemberian $33 \mathrm{mM}$ pada HUVEC's sebagai model eksperimental kejadian GDM. Konsentrasi glukosa $33 \mathrm{mM}$ secara in vitro setara dengan $594 \mathrm{mg} / \mathrm{dl}$ merupakan konsentrasi patologis dan paparan 3 hari sudah menyebabkan AGE (Advance Glycosylated Endproduct) yang tergolong irreversible. Kultur primer sel trofoblas yang telah konfluen setelah 3 hari dikelompokkan menjadi 2 kelompok perlakuan, yaitu (1) glukosa normal (5 mM sebagai kontrol negatif) dan dengan paparan glukosa $33 \mathrm{mM}$ (kontrol positif), masing-masing kelompok dibagi menjadi 2 sub kelompok, yaitu (a) tanpa perlakuan polifenol teh hijau dan (b) perlakuan polifenol teh hijau 0,$1 ; 0,2$; dan $0,4 \mathrm{mg} / \mathrm{ml}$. Selanjutnya setiap perlakuan dikultur dalam inkubator

$\mathrm{CO} 25 \%$, suhu $37^{\circ} \mathrm{C}$ selama 3 hari.

\section{Karakterisasi Sel Sitotrofoblas dengan Metode Imunositokimia}

Kultur trofoblas yang telah dipanen, dilakukan karakterisasi sel sitotrofoblas dengan metode imunositokimia. Kultur trofoblas dicuci dengan PBS pH 7,4 selama $3 \times 5$ menit dan difiksasi dengan methanol absolut selama \pm 2 menit. Dicuci kembali dengan PBS pH 7,4 selama

$3 \times 5$ menit. Kemudian dilakukan blocking endogenous peroxidase dengan $3 \% \mathrm{H} 2 \mathrm{O} 2$ selama 20 menit, dicuci dengan PBS pH 7,4 selama $3 \times 5$ menit. Kemudian dilakukan blocking unspecific protein dengan serum $5 \%$ FBS yang mengandung $0,25 \%$ Triton X-100 dan diinkubasi selama 1 jam pada suhu ruang. Kemudian dicuci dengan PBS pH 7,4 selama $3 \times 5$ menit dan diinkubasi dengan antibodi Mouse Anti-Human Cytokeratin-7 (1:500) selama overnight pada $4^{\circ} \mathrm{C}$. Plate 6 well dikeluarkan dari refrigerator dan didiamkan pada suhu ruang selama 30 menit. Dicuci dengan PBS pH 7,4 selama $3 \times 5$ menit. Diinkubasi menggunakan antibodi sekunder Goat Anti Mouse IgG biotin conjugated 1:500 (Kirkegaard dan Perry Lab) selama 11,5 jam. Dicuci dengan PBS pH 7,4 selama $3 \times 5$ menit dan ditetesi dengan SA-HRP 
(Strep-Avidin Horse Radish Peroxidase), diinkubasi selama 40-60 menit pada suhu ruang. Dicuci dengan PBS pH 7,4 selama 3x5 menit dan ditetesi kromogen untuk HRP, yaitu DAB (3,3-Diamino Benzidine) yang dilarutkan dalam DAB buffer/peroxide (Sigma) dan diinkubasi selama 30-60 menit. Dicuci dengan PBS pH 7,4 selama 3x5 menit. Dilakukan counterstain dengan Mayer Hematoxylen (1:10) selama 10 menit. Kemudian dibilas dengan air kran dan cuci dengan akuades, dikeringkan.

Dilakukan mounting dengan entellan dan ditutup dengan coverglass selanjutnya diamati pada mikroskop cahaya dengan perbesaran 400X.

\section{Pengukuran Kadar Sitokin Proinflamasi TNF-a dengan Metode ELISA}

Kadar TNF-á pada kultur media dikuantifikasi menggunakan immunoassay dengan metode ELISA. Pengukuran TNF-á dilakukan dengan menggunakan dua antibodi monoklonal yaitu capture antibody dan recapture antibody. Dilakukan coating antigen dengan menggunakan 100 ìl calibrator diluent II untuk standart Ditambahkan medium sampel yang telah disentrifugasi (50 ìl) dan antibodi primer (50 ìl), sedangkan penambahan protein standar sebanyak 100 ìl (Human TNF-á). Selanjutnya diinkubasi pada pada mikroplate 96 well selama over night pada $4^{\circ} \mathrm{C}$. Plate 96 well dikeluarkan dari refrigerator dan didiamkan pada suhu ruang selama 30 menit. Selanjutnya dicuci dengan washing buffer 3x@200 ìl lalu diinkubasi dengan antibodi sekunder Goat anti Human IgG yang berlabel biotin dalam PBS yang mengandung BSA (Bovine Serum Albumin) 1\% (1:100) @ 100 il, diinkubasi pada shaker selama 1 jam pada suhu ruang. Dicuci dengan washing buffer 3x @ 200 il dan ditetesi Strepavidin HRP $(1: 1500)$ diinkubasi selama 40 menit pada shaker. Dicuci dengan washing buffer 3x @200 il dan diinkubasi dengan substrat buffer A dan B @ 100 ìl selama 30 menit dalam ruangan gelap lalu diteteskan stop reaction, selama 10 menit dan dibaca pada ELISA reader pada ë $450 \mathrm{~nm}$

\section{Pengamatan Jumlah Sel yang Mengekspresikan TNF-a dengan Metode Imunositokimia}

Jumlah sel yang mengekspresikan TNF-á dapat diketahui dengan metode staining immunohistochemistry. Kultur trofoblas dicuci dengan PBS pH 7,4 selama $3 \times 5$ menit dan difiksasi dengan methanol absolut selama \pm 2 menit. Dicuci kembali dengan PBS pH 7,4 selama $3 \times 5$ menit. Kemudian dilakukan blocking endogenous peroxidase dengan $3 \% \mathrm{H} 2 \mathrm{O} 2$ selama 20 menit, dicuci dengan PBS pH 7,4 selama 3x5 menit. Kemudian dilakukan blocking unspecific protein dengan serum 5\% FBS yang mengandung $0,25 \%$ Triton X-100 dan diinkubasi selama 1 jam pada suhu ruang. Kemudian dicuci dengan PBS pH 7,4 selama $3 \times 5$ menit dan diinkubasi dengan antibodi Anti-Mouse TNF-á (1:1000) selama overnight pada $4^{\circ} \mathrm{C}$. Plate 6 well dikeluarkan dari refrigerator dan didiamkan pada suhu ruang selama 30 menit. Dicuci dengan PBS pH 7,4 selama $3 \times 5$ menit. Diinkubasi menggunakan antibodi sekunder Goat Anti Mose IgG biotin conjugated 1:500 (Kirkegaard dan Perry Lab) selama 1-1,5 jam. Dicuci dengan PBS $\mathrm{pH} 7,4$ selama $3 \times 5$ menit dan ditetesi dengan SA-HRP (Strep-Avidin Horse Radish Peroxidase), diinkubasi selama 40-60 menit pada suhu ruang. Dicuci dengan PBS pH 7,4 selama $3 \times 5$ menit dan tetesi kromogen untuk HRP, yaitu DAB (3,3-Diamino Benzidine) yang dilarutkan dalam $\mathrm{DAB}$ buffer/peroxide (Sigma) dan diinkubasi selama30-60 menit. Dicuci dengan PBS pH 7,4 selama 3x5 menit. Dilakukan counterstain dengan Mayer Hematoxylen (1:10) selama 10 menit. Kemudian dibilas dengan air kran dan cuci dengan akuades, dikeringkan. Dilakukan mounting dengan entellan dan ditutup dengan coverglass selanjutnya diamati pada mikroskop cahaya dengan perbesaran 400X.

\section{Penyajian dan Analisis Data}

Data kuantitatif kadar TNF-á hasil ELISA dibandingkan pada setiap kelompok perlakuan menggunakan Analisis Varian satu arah (One Way ANOVA) menggunakan SPSS (Statistic Package For Social Science) versi 12 for Window. Data ekspresi TNF-á diperoleh dengan cara menghitung nilai positif berwarna coklat pada daerah sitoplasma sel trofoblas yang dinyatakan dalam bentuk persentase dan dianalisis secara deskriptif.

\section{Hasil dan Pembahasan Isolasi dan Kultur Sel Trofoblas Plasenta Manusia}

Sel trofoblas yang digunakan dalam 
penelitian ini diisolasi dari jaringan plasenta manusia dengan kriteria inklusi sampel yang berasal dari persalinan sectio caessaria dan kondisi kehamilan fisiologis, sedangkan kriteria eksklusi dari sampel yang digunakan adalah kehamilan dengan preeklampsia/ eklampsia, hipertensi, premature atau gestasional diabetes. Jaringan plasenta disimpan dalam medium transport cord solution yang mengandung HBSS, HEPES, NaBic-Phenol Red dan gentamicin untuk mempertahankan kondisi fisiologis sel trofoblas karena mengandung nutrisi berupa asam amino, ion organik dan mempertahankan $\mathrm{pH}$ fisiologis \pm 7.4 serta terhindar dari kontaminasi.

Sel trofoblas yang sudah dicacah dengan metode mekanik harus segera dikultur paling lama 12 jam setelah proses persalinan agar didapatkan kondisi sel yang dapat mengalami pertumbuhan secara optimal. Sel trofoblas dibersihkan dengan larutan Phosphate Buffer Saline A (PBS-A) yang tidak mengandung $\mathrm{Ca} 2+$ dan $\mathrm{Mg} 2+$. Sel trofoblas yang digunakan sebagai sampel dalam penelitian ini diperoleh dari plasenta karena sel trofoblas merupakan sel epitel komponen penyusun jaringan plasenta yang berfungsi sebagai transpor nutrisi antara maternal dan fetal. Isolasi dan kultur sel trofoblas dilakukan berdasarkan modifikasi dari metode isolasi secara enzimatik menurut Jones (1996). Sel trofoblas ditumbuhkan dalam medium M-199 yang mengandung $10 \%$ FBS (Lampiran 1) pada plate 6 well yang dilapisi dengan gelatin $(0,2 \%$ selama \pm 30 -60 menit) sebagai matriks ekstraseluler. Elizabeth, et al., (1998) melakukan kultur sel endotel dengan dilapisi gelatin $0,2 \%$ selama 30 menit. Menurut Biological Industries (2002), gelatin solution $0.2 \%$ berfungsi untuk melapisi botol kultur atau plates yang digunakan untuk menumbuhkan sel, misalnya mouse Embrionic Stem cells. Menurut Sigma Aldrich (2008), normal attachment, pertumbuhan, dan perkembangan dari beberapa jenis sel tergantung pada faktor attachment dan komponen matriks ekatraseluler. Meskipun beberapa jenis sel mampu mensistesis komponen tersebut, namun beberapa jenis sel yang lain membutuhkan komponen tersebut sebagai sumber eksogen, terutama ketika ditumbuhkan pada medium kultur serumfree.

Faktor attachment dan komponen matriks ekatraseluler diperlukan untuk memfasilitasi pertumbuhan sel, morfologi, diferensiasi, motilitas sel, dan meningkatkan attachment serta penyebaran sel. Beberapa contoh faktor attachment dan komponen matriks ekatraseluler antara lain collagen, gelatin, fibronectin, dan laminin. Kultur sel trofoblas diinkubasi dalam inkubator 5\% $\mathrm{CO} 2$ pada suhu $37^{\circ} \mathrm{C}$ sampai sel mengalami confluent selama \pm 3 hari. Setelah 24 jam media kultur harus diganti karena setelah 24 jam rentan terjadi kontaminasi. Pada perlakuan selanjutnya, penggantian medium dilakukan setiap 2 hari sekali. Hasil kultur primer sel trofoblas ditunjukkan pada Gambar 1.

Pada pengamatan di bawah mikroskop fase kontras, gambar 1 (A) menunjukkan kultur sel sebelum 24 jam, sebagian kumpulan sel sudah attach (menempel pada coverslip di dasar well) dengan menggunakan matriks ekstraseluler gelatin $0,2 \%$ ) namun sel masih belum mengalami perkembangan. Sedangkan pada gambar 1 (B) kultur setelah 72 jam, sebagian besar sel telah attach pada coverslip di dasar well dan sel telah berkembang yang ditandai dengan adanya perluasan sel. Hal ini menunjukkan bahwa sel mengalami pertumbuhan dan telah konfluen. Namun belum didapatkan sel monolayer yang outgrowth atau keluar dari eksplan karena sel masih terikat pada eksplan. Kumpulan sel diduga terdapat di tepi eksplan yang bersifat transparan. Hasil kultur yang didapatkan pada penelitian ini sesuai dengan hasil kultur eksplan trofoblas plasenta manusia yang dilakukan oleh Black, et al., (2003) yang menunjukkan kumpulan sel yang bersifat transparan yang terletak di tepi eksplan

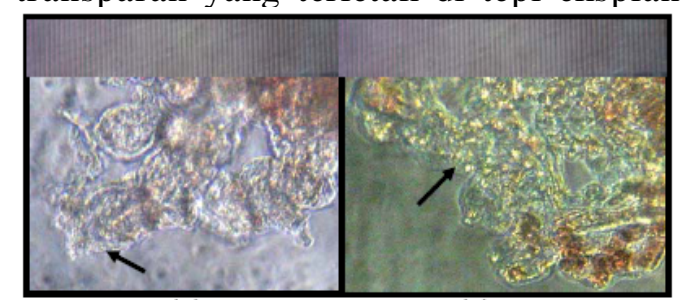

Gambar 1. Morfologi kultur prin plasenta manusia (Diamati pada mikroskop fase kontras merk Olympus dengan perbesaran 200X). (A) sebelum 24 jam (B) setelah 72 jam

KETERANGAN: 1 Bar $=0,1$ ìm. Gambar anak panah menunjukkan kumpulan sel yang terletak di tepi eksplan yang bersifat transparan 


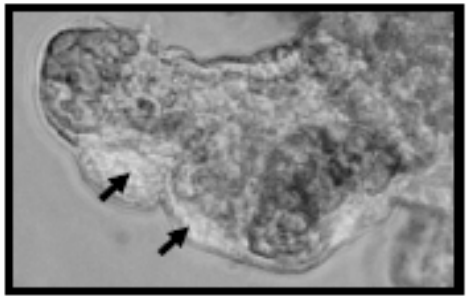

Gambar 2. Morfologi kultur eksplan trofoblas plasenta manusia (Diamati pada mikroskop fase kontras dengan perbesaran 200X) setelah diinkubasi selama 1 jam (Black et al., 2003). Gambar anak panah menunjukkan kumpulan sel yang terletak di tepi eksplan yang bersifat transparan.

\section{Karakterisasi Sel Sitotrofoblas Plasenta Manusia dengan Metode Imunositokimia}

Sebagian besar trofoblas tersusun atas sel sitotrofoblas (berinti satu) dan sel sinsisiotrofoblas (berinti banyak). Pada penelitian ini dilakukan karakterisasi sel sitotrofoblas melalui metode imunositokimia dengan menggunakan antibodi monoklonal mouse anti human cytokeratine-7 dan antibodi sekunder goat anti mouse IgG biotin conjugate dengan menggunakan kromogen DAB (3,3- diaminobenzidine tetrahydrochloride). Sebelum dilakukan pengecatan, sel difiksasi terlebih dahulu dengan menggunakan metanol absolut yang bertujuan untuk membunuh sel tanpa mengubah stukturnya.Karakterisasi sel sitotrofoblas plasenta bertujuan untuk memastikan bahwa sel yang dikultur adalah sel trofoblas. Hal ini dilakukan karena teknik isolasi yang digunakan pada penelitian ini adalah teknik mekanik atau dengan cara dicacah sehingga dimungkinkan tidak diperoleh isolat sel trofoblas murni dan masih terdapat beberapa jenis sel lain. Menurut hasil penelitian Keman (2005) menunjukkan bahwa hasil isolasi sel sitotrofoblas melalui teknik enzimatis masih belum didapatkan sel sititrofoblas murni karena masih ditemukan sel sinsisiotrofoblas. Hasil karakterisasi sel sitotrofoblas plasenta ditunjukkan pada Gambar 3.

Gambar 3 menunjukkan bahwa sel-sel sitotrofoblas nampak jelas terwarnai coklat pada sitoplasmanya berdasarkan kemampuan pengikatan terhadap kromogen DAB. Sitoplasma sel sitotrofoblas terwarnai coklat yang menandakan visualisasi kromogen
DAB yang berikatan dengan peroxidase pada SA-HRP yang menunjukkan adanya ekspresi cytokeratine pada sel sitotrofoblas. Counterstain Hematoxillen akan mewarnai inti sel menjadi biru keunguan. Menurut hasil penelitian sebelumnya yang dilakukan oleh Keman(2005) sel sitotrofoblas dapat dibedakan dengan sel sinsisiotrofoblas berdasarkan kemampuan pengikatan terhadap kromogen DAB sehingga menunjukkan warna coklat pada sitoplasma. Sitoplasma sel sitotrofoblas nampak jelas terwarnai coklat yang menunjukkan adanya ekspresi cytokeratine sedangkan sitoplasma sel sinsisiotrofoblas akan menunjukkan warna biru keunguan yang menunjukkan tidak adanya ekspresi cytokeratine. Hasil karakterisasi sel sitotrofoblas yang didapatkan pada penelitian ini sesuai dengan hasil karakterisasi sel sitotrofoblas plasenta manusia yang dilakukan melalui isolasi secara enzimatik oleh Black, et al., (2003) yang menunjukkan sitoplasma sel sitotrofoblas berwarna kecoklatan sedangkan sitoplasma sel dan inti sel sinsisiotrofoblas menunjukkan warna biru seperti tampak pada Gambar 4

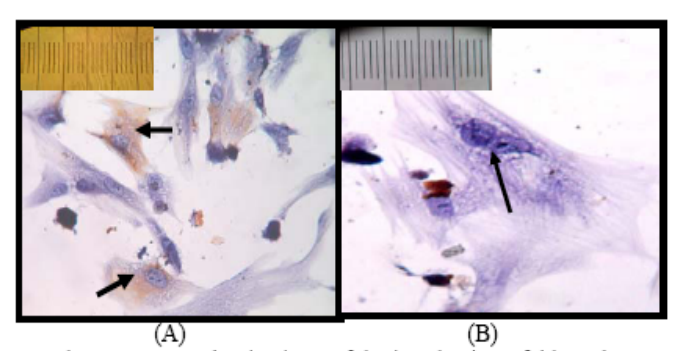

Gambar 3. Karakterisasi morfologi sel sitotrofoblas dengan antibodi monoklonal Mouse Anti Human Cytokeratine-7 (Diamati pada mikroskop cahaya dengan perbesaran 400X) (A) Sitotrofoblas (B) Sinsitiotrofoblas KETERANGAN: 1 Bar $=0,1$ ìm

Gambar 3 menunjukkan bahwa sel-sel sitotrofoblas nampak jelas terwarnai coklat pada sitoplasmanya berdasarkan kemampuan pengikatan terhadap kromogen DAB. Sitoplasma sel sitotrofoblas terwarnai coklat yang menandakan visualisasi kromogen DAB yang berikatan dengan peroxidase pada SA-HRP yang menunjukkan adanya ekspresi cytokeratine pada sel sitotrofoblas. Counterstain Hematoxillen akan mewarnai inti sel 
menjadi biru keunguan. Menurut hasil penelitian sebelumnya yang dilakukan oleh Keman(2005) sel sitotrofoblas dapat dibedakan dengan sel sinsisiotrofoblas berdasarkan kemampuan pengikatan terhadap kromogen DAB sehingga menunjukkan warna coklat pada sitoplasma. Sitoplasma sel sitotrofoblas nampak jelas terwarnai coklat yang menunjukkan adanya ekspresi cytokeratine sedangkan sitoplasma sel sinsisiotrofoblas akan menunjukkan warna biru keunguan yang menunjukkan tidak adanya ekspresi cytokeratine. Hasil karakterisasi sel sitotrofoblas yang didapatkan pada penelitian ini sesuai dengan hasil karakterisasi sel sitotrofoblas plasenta manusia yang dilakukan melalui isolasi secara enzimatik oleh Black, et al., (2003) yang menunjukkan sitoplasma sel sitotrofoblas berwarna kecoklatan sedangkan sitoplasma sel dan inti sel sinsisiotrofoblas menunjukkan warna biru seperti tampak pada Gambar 4.

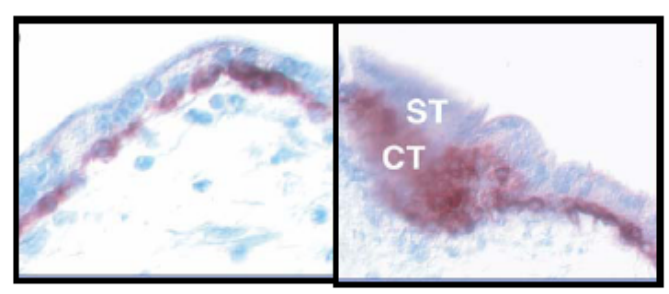

(A)

(B)

Gambar 4. Karakterisasi morfologi sel trofoblas dengan antibody Cytokeratine-7 (A) Diamati dengan perbesaran 400X (B) Diamati pada perbesaran 960X (Black et al., 2003) KETERANGAN: ST =syncytiotrophoblast, $\mathrm{CT}=$ cytotrophoblast

Menurut hasil penelitian Keman (2005), sel-sel sitotrofoblas dapat dibedakan dengan sel sinsisiotrofoblas berdasarkan morfologinya dengan cara memulas protein sitokeratin yang terdapat pada sitoplasma sel sitotrofoblas dengan metode imunohistokimia menggunakan antibodi monoklonal Anti Sitokeratin PKK1 serta antibodi sekunder mouse anti biotin conjugate yang menunjukkan karakteristik sel sitotrofoblas. Sel sitotrofoblas nampak sebagai sel-sel tunggal dengan batas sel yang tegas, inti tunggal dengan sitoplasma amorf (tidak beraturan) dan sitoplasma sel tampak jelas karena terwarnai kuat kecoklatan oleh bahan kromogen $\mathrm{H} 2 \mathrm{O} 2 \mathrm{DAB}$, sedangkan sel sinsisiotrofoblas nampak sebagai kumpulan sel dengan batas yang tidak jelas dan berinti banyak. Hal ini sesuai dengan Black et al., (2003) yang melaporkan bahwa antibodi cytokeratine- 7 merupakan marker untuk vilus sitotrofoblas. Prinsip dari imunositokimia adalah deteksi protein spesifik dengan menggunakan reaksi antigen-antibodi. Protein target yang terdapat pada sel akan diikat oleh antibodi primer, kemudian antibody primer akan diikat oleh antibodi sekunder. Biotin yang terdapat pada antibodi sekunder akan berikatan dengan avidin pada enzim SA-HRP membentuk kompleks strepavidin-biotin. Kromogen DAB akan berikatan kuat dengan peroksidase yang terdapat pada SA-HRP membentuk warna coklat

\section{Pengukuran Kadar Sitokin Proinflamasi TNF-a dengan Metode ELISA (Rosen, $e t$ al., 1998)}

Pada penelitian eksperimental ini, kultur sel trofoblas normal dipapar dengan glukosa tinggi $33 \mathrm{mM}$ selama 3 hari diharapkan mampu menginduksi terjadinya hiperglukosa (sebagai model hiperglikemia) dan meningkatnya pembentukan ROS intraseluler yang berimplikasi terhadap terjadinya inflamasi. Terjadinya inflamasi pada kultur sel trofoblas salah satunya ditandai dengan terjadinya peningkatan TNFa yang diproduksi oleh sel. Peningkatan kadar TNF-a dapat diukur dengan menggunakan ELISA yang dinyatakan dalam bentuk unit absorbansi pada panjang gelombang $450 \mathrm{~nm}$. Berdasarkan hasil pengukuran kadar sitokin proinflamasi TNFa pada perlakuan hari ke-3 dengan tiga kali ulangan didapatkan rata-rata kadar TNF-a seperti tercantum pada Tabel 1.

Tabel 1. Rerata hasil pengukuran kadar TNF-a pada kultur sel trofoblas dengan ELISA $(n=3)$

\begin{tabular}{|c|c|c|}
\hline \multirow{2}{*}{$\begin{array}{c}\text { Konsentrasi } \\
\text { polifenol } \\
\text { teh hijall } \\
(\mathrm{mg} / \mathrm{ml})\end{array}$} & \multicolumn{2}{|c|}{ Kadar TNF- $\alpha .(\rho g / m)$} \\
\hline & Glukosa Normal & Paparan glukosa $33 \mathrm{mV}$ \\
\hline 0 (Kontrol) & $2739,889 \pm 191,668^{\mathrm{a}}$ & $2621,000 \pm 289,123^{\mathrm{a}}$ \\
\hline 0,1 & $2804,333 \pm 66,583^{\mathrm{a}}$ & $2721,000 \pm 171,561^{\mathrm{a}}$ \\
\hline 0,2 & $2513,222 \pm 194,403^{\mathrm{a}}$ & $2612,111 \pm 45,501^{\mathrm{a}}$ \\
\hline 0,4 & $2592,111 \pm 41,141^{a}$ & $2566,555 \pm 96,743^{\mathrm{a}}$ \\
\hline
\end{tabular}


Grafik rerata kadar TNF-a pada sel trofoblas yang dipengaruhi oleh paparan glukosa dan perlakuan polifenol teh hijau selama 3 hari dapat ditunjukkan pada Gambar 5. Kultur Sel Trofoblas Normal dan Dipapar Glukosa $33 \mathrm{mM}$ selama 3 hari terhadap Kadar TNF-a dengan Metode ELISA. Berdasarkan hasil uji statistik BNJ $(\mathrm{p}<0.05)$ menunjukkan bahwa tidak ada perbedaan signifikan pada semua kelompok perlakuan terhadap kadar TNF-a ( $\mathrm{p}>0.05)$. Tabel 1 dan Gambar 5 menunjukkan bahwa hasil pengukuran kadar TNF-a pada kelompok paparan glukosa $33 \mathrm{mM}(2621,00$ $\tilde{n} \mathrm{~g} / \mathrm{mL} \pm 289,123$ ) lebih rendah tetapi tidak signifikan dibandingkan dengan glukosa normal (kontrolnegatif) $(2739,889 \tilde{\mathrm{n} g} / \mathrm{mL} \pm$ 191,668). Berdasarkan analisis tersebut tampak bahwa pemaparan glukosa tinggi 33 $\mathrm{mM}$ pada kultur sel trofoblas pada hari ke-3 belum mampu meningkatkan kadar TNF-a. Hal ini menunjukkan bahwa pada kondisi normal (tanpa pemaparan glukosa tinggi) terjadi produksi TNF-a. Pada kondisi basal TNF-a diproduksi oleh tubuh, namun adanya endotoksin atau mikroorganisme dapat meningkatkan produksi TNF-a yang merupakan modulator potensial pada imun dan respon inflamasi. Selain itu, pada kondisi kehamilan normal, terdapat produksi TNF-a seperti yang telah dilaporkan oleh Kirwan, et al., (2002) bahwa munculnya sitokin proinflamatori terkait dengan kejadian seluler yang menentukan dan memelihara kehamilan, namun perannya secara spesifik masih belum diketahui dengan jelas.

Pada wanita hamil yang normal, TNF-á diduga memodulasi pertumbuhan dan invasi trofoblas pada arteri spiral maternal.

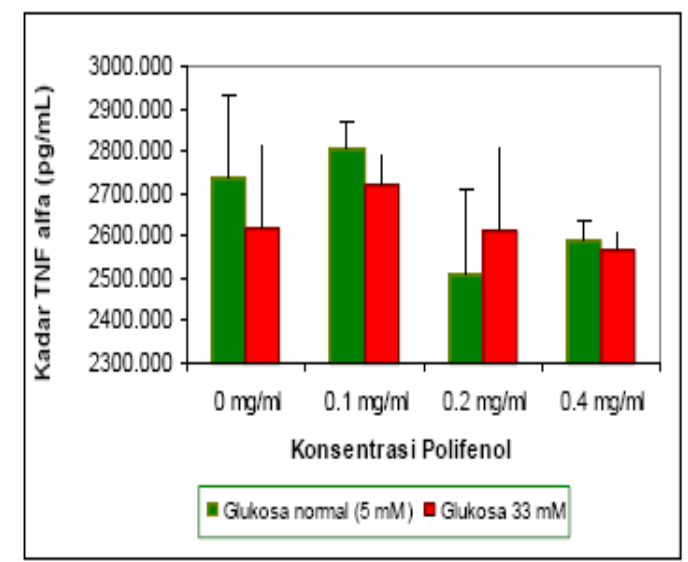

Gambar 5. Rerata Konsentrasi Polifenol Teh hijau $(\mathrm{mg} / \mathrm{mL})$ pada sel trofoblas
Pemaparan glukosa $33 \mathrm{mM}$ diasumsikan sudah mampu menunjukkan kondisi hiperglukosa yang dapat mempengaruhi proses metabolisme ROS sehingga dapat memicu terjadinya inflamasi pada kultur sel trofoblas. Hal ini telah dibuktikan pada penelitian sebelumnya oleh Khotimah (2003), bahwa konsentrasi glukosa $33 \mathrm{mM}$ secara in vitro pada sel HUVEC's setara dengan $594 \mathrm{mg} / \mathrm{dl}$ yang merupakan konsentrasi patologis jika dibandingkan dengan kadar gula darah normal dengan kisaran 80-120 mg/dl. Penurunan kadar TNFá pada sel trofoblas yang dipapar glukosa tinggi dimungkinkan karena waktu pemaparan glukosa tinggi dan pengukuran kadar TNF-a pada hari ke-3 sudah melewati batasan pengeluaran maksimal TNF-a. Hal ini merujuk pada hasil penelitian Yang, et al., (1998) yang menyebutkan bahwa produksi TNF-a dimulai setelah 6 jam dan mencapai puncak setelah 24 jam paparan.

Oleh karena itu dimungkinkan pemaparan glukosa pada hari ke-3 telah mampu menyebabkan sel mengalami adaptasi terhadap kondisi hiperglukosa setelah sebelumnya mengalami kompensasi dengan adanya peningkatan produksi TNFa setelah 24 jam paparan. Selain itu, kemungkinan tiap jenis sel memiliki kemampuan metabolisme yang berbeda terhadap glukosa seperti dilaporkan dalam hasil penelitian Ceolotto (2007) bahwa terjadi peningkatan produksi ROS intraseluler pada kultur HUVEC's yang dipapar glukosa selama 48 jam dengan konsentrasi $10 \mathrm{mmol} / \mathrm{L}$ dibandingkan dengan pemaparan glukosa $5 \mathrm{mmol} / \mathrm{L}$ (normal) dan pada penelitian yang telah dilakukan oleh Khotimah (2003), dengan pemaparan glukosa $33 \mathrm{mM}$ selama 3 hari pada kultur HUVEC's menyebutkan bahwa secara in vitro, konsentrasi glukosa $33 \mathrm{mM}$ setara dengan $594 \mathrm{mg} / \mathrm{dl}$ merupakan konsentrasi patologis dan paparan 3 hari sudah menyebabkan AGE yang tergolong irreversible. Glukosa masuk ke dalam sel dapat melalui difusi pasif terfasilitasi oleh protein transporter glukosa GLUT. Pada penelitian ini, pemaparan sel trofoblas oleh glukosa konsentrasi tinggi menyebabkan glukosa masuk ke dalam sel melalui difusi pasif berdasarkan perbedaan konsentrasi glukosa antara media ekstraseluler dengan sel dengan difasilitasi protein transporter glukosa GLUT1 karena tidak terdapatnya keterlibatan 
insulin. Tingginya kadar glukosa pada sel trofoblas pada akhirnya dapat menghasilkan suatu senyawa yang berbahaya bagi jaringan tubuh, salah satunya adalah $\mathrm{H} 2 \mathrm{O} 2$ dan meningkatkan pembentukan radikal bebas melalui berbagai mekanisme. Radikal bebas juga mempercepat pembentukan AGEs yang pada gilirannya menghasilkan lebih banyak radikal bebas. Proses ini disebut autooksidasi glukosa. Peningkatan autooksidasi glukosa mampu menyebabkan reduksi molekul oksigen dan menghasilkan oxygen intermediates. Reduksi produk-produk oksigen yang dihasilkan reaksi autooksidasi adalah anion superoksid $(\mathrm{O} 2 \bullet-)$, hidrogen peroksida $(\mathrm{H} 2 \mathrm{O} 2)$, dan radikal hidroksil $(\mathrm{OH} \bullet)$ yang sangat berbahaya oleh karena sangat reaktif dan dapat menyebabkan kerusakan membran sel, protein dan DNA(Halliwel dan Gutteridge, 1998). Akumulasi H2O2 dapat berbahaya bila terdapat bersama dengan ion $\mathrm{Fe} 2+$ atau chelating agent (Lautan, 1997).

Menurut Nusindrati (2003) kadar glukosa yang tinggi akan dimetabolisme melalui berbagai proses, salah satunya melalui proses glukooksidasi menghasilkan radikal superoksida yang akan menyebabkan stres oksidatif dan berpengaruh pada fungsi dan integritas sel. Kondisi glukosa tinggi akan memicu meningkatnya produksi ROS yang turut berperan dalam diabetogenesis dan perkembangan komplikasi lanjut dari DM (Jakus, 2000). ROS mempunyai implikasi pada aktivasi faktor transkripsi NF$\mathrm{kB}$ yang peka terhadap responstres oksidatif (Haddad, 2002). NF-kB pada keadaan normal berada di sitoplasma dalam keadaan inaktif yang berikatan dengan inhibitor $\mathrm{kB}$ (IkB), aktivasi NF-kB akan berakibat translokasi $\mathrm{kB}$ menuju nukleus dan bersifat aktif (Collins dan Cybulsky, 2001). Aktivasi NF-kB yang merupakan suatu protein yang dapat menginduksi transkripsi beberapa jenis gen dapat merangsang inflamasi dengan menginduksi produksi berbagai mediator inflamasi, seperti TNF-á. Konsentrasi glukosa $33 \mathrm{mM}$ diasumsikan sudah mampu menstimulus peningkatan produksi TNF-a pada sel trofoblas melalui aktivasi NF-kB.

Kondisi stres oksidatif berkaitan dengan patogenesis beberapa macam penyakit kronis. Stres oksidatif adalah kondisi gangguan keseimbangan antara oksidan dan antioksidan yang berpotensi menimbulkan kerusakan. Menurut Zhao (2001), stres oksidatif secara signifikan meningkat pada diabetes karena ekspos yang panjang pada kondisi hiperglikemia dapat meningkatkan pembentukan radikal bebas dan mereduksi kapasitas sistem pertahanan antioksidan. Hiperglikemia sebagai penyebab utama diabetes telah diketahui sebagai suatu hal yang esensial bagi perkembangan komplikasi diabetes. Menurut Suparman (2003), apabila hiperglikemia sebagai penyebab stres oksidatif ini diderita oleh wanita hamil (biasanya disebut sebagai peristiwa gestation Diabetes Mellitus), maka kondisi ini tidak hanya membahayakan maternal namun juga akan membahayakan janin yang dikandungnya. Pada keadaan normal, terdapat keseimbangan antara oksidan dan antioksidan. Bila keseimbangan ini beralih ke arah kelebihan oksidan, maka keadaan ini disebut stres oksidatif.

Menurut Lautan (1997), proses metabolisme tubuh cenderung menghasilkan berbagai oksidan kuat, misalnya radikal hidroksil merupakan oksidan yang paling toksik karena dapat bereaksi dengan bermacam-macam senyawa elementer seperti protein, asam nukleat, lipid dan lainlainsehingga dapat dengan mudah dan cepat merusak struktur sel ataujaringan serta memicu terjadinya inflamasi yang berimplikasi pada patologis. Kadar TNF-a yang diberi perlakuan polifenol teh hijau 0,1 $\mathrm{mg} / \mathrm{mL}$ pada glukosa normal $(2804,33$ ñg/ $\mathrm{mL} \pm 66,583$ ) lebih tinggi tetapi tidak signifikan daripada kontrol negatif $(2739,889$ $\tilde{\mathrm{n} g} / \mathrm{mL} \pm 191,668)$. Namun pada perlakuan glukosa normal serta polifenol the hijau dengan konsentrasi 0,2 dan $0,4 \mathrm{mg} / \mathrm{ml}$ pada terjadi penurunan kadar TNF-a berturut-turut sebesar $(2513,222 \tilde{n} \mathrm{~g} / \mathrm{mL} \pm 194,403)$ dan $(2592,111 \tilde{n} \mathrm{~g} / \mathrm{mL} \pm 41,141)$ dibandingkan dengan kontrol negative $(2739,889 \tilde{\mathrm{ng}} / \mathrm{mL} \pm$ 191,668) meskipun tidak signifikan ( $p>0.05$ ) berdasarkan hasil uji statistik. Perubahan kadar TNF-a yang tidak signifikan pada perlakuan polifenol teh hijau dan glukosa normalmengindikasikan bahwa polifenol teh hijau tidak bersifat toksik pada kondisi normal. Demikian halnya pada kultur yang diberi pemaparan glukosa $33 \mathrm{mM}$ serta perlakuan polifenol teh hijau pada konsentrasi $0,1 \mathrm{mg} / \mathrm{mL}(2721,000 \tilde{\mathrm{n}} / \mathrm{mL} \pm$ 171,561) mengalami peningkatan kadar TNF-a tetapi tidak signifikan dibandingkan dengan kontrol positif $(2621,000 \tilde{n} \mathrm{~g} / \mathrm{mL} \pm$ $289,123)$. Namun pada perlakuan polifenol the hijau dengan konsentrasi 0,2 dan 0,4 mg/ 
mL terjadi penurunan kadar TNF-a berturutturut sebesar $(2612,111 \tilde{\mathrm{ng}} / \mathrm{mL} \pm 45,501)$ dan (2566,555 $\tilde{\mathrm{ng}} / \mathrm{mL} \pm 96,743)$ dibandingkan dengan kontrol positif $(2621,000 \tilde{n} \mathrm{~g} / \mathrm{mL} \pm$ $289,123)$ meskipun tidak signifikan ( $p>0.05$ ) berdasarkan hasil uji statistik.

Hal ini menunjukkan bahwa paparan polifenol selama 3 hari pada konsentrasi 0,1 ; 0,2 ; dan $0,4 \mathrm{mg} / \mathrm{mL}$ menghasilkan resultanse kadar TNF-a yang tidak signifikan. Hal ini kemungkinan disebabkan kisaran konsentrasi perlakuan polifenol teh hijau yang diberikan belum mampu menurunkan kadar TNF-a pada sel trofoblas. Teh hijau terbukti memiliki efek antioksidan baik secara in vitro maupun in vivo. Sebagian besar efek antioksidan teh berasal dari fraksi polifenol. Hal ini dibuktikan oleh hasil penelitian yang dilakukan oleh Lin dan Lin (1997) melaporkan bahwa pada dosis 5 dan 10 mmol/L EGCG yang diberikan secara bersamaan dengan LPS pada tikus secara in vivo dapat menghambat aktivasi NF-kB sebesar 40\%. Yang, et al., (1998) menunjukkan peran teh hijau sebagai anti inflamasi, independen dari efek antioksidan teh hijau dengan penghambatan NF-kB sehingga menurunkan pembentukan sitokin proinflamasi (TNF-a dan IL-1). Perlakuan polifenol teh hijau pada konsentrasi 0,$1 ; 0,2$ dan $0,4 \mathrm{mg} / \mathrm{ml}$ yang diberikan secara bersamaan dengan glukosa $33 \mathrm{mM}$ selama 3 hari belum mampu menurunkan kadar TNFa secara signifikan pada kultur sel trofoblas meskipun pada jenis sel lain menunjukkan hasil yang berbeda. Hasil penelitian yang telah dilakukan oleh Sianne (2006) menunjukkan bahwa pemberian polifenol teh hijau pada konsentrasi 0,$1 ; 0,2$ dan $0,4 \mathrm{mg} /$ ml selama 2 jam sebelum pemaparan LDL teroksidasi $50 \mathrm{ìg} / \mathrm{ml}$ selama 30 menit telah terbukti secara signifikan dapat menurunkan aktivasi NF-kB dan dan ekspresi TNF-a pada kultur sel endotel. Konsentrasi polifenol teh hijau 0,$1 ; 0,2$ dan $0,4 \mathrm{mg} / \mathrm{mL}$ mampu menurunkan ekspresi TNF-a secara signifikan, meskipun pada dosis 0,2 dan 0,4 $\mathrm{mg} / \mathrm{mL}$ tidak terjadi penurunan ekspresi TNF-a yang signifikan.

\section{Pengamatan Jumlah Sel yang Mengekspresikan TNF-a dengan Metode Imunositokimia}

Terjadinya inflamasi pada kultur sel trofoblas salah satunya ditandai dengan terjadinya peningkatan jumlah sel yang mengekspresikan TNF-a. Peningkatan jumlah sel yang mengekspresikan TNF-a dapat dideteksi dengan menggunakan teknik imunositokimia. Ekspresi TNF-a pada sel trofoblas ditandai dengan terbentuknya warna coklat pada sitoplasma sedangkan inti sel berwarna biru keunguan (Gambar 4.24.4). Warna coklat menandakan visualisasi kromogen $\mathrm{DAB}$ yang berikatan dengan peroxidase pada SA-HRP yang menandakan adanya ekspresi TNF-a pada sel trofoblas. Adanya ekspresi TNF-a yang dideteksi melalui imunositokimia menunjukkan bahwa memang terjadi produksi TNF- a pada sel trofoblas baik dalam kondisi normal maupun melalui paparan glukosa. Hasil imunositokimia untuk mendeteksi ekspresi TNF-a ditunjukkan pada Gambar 6.

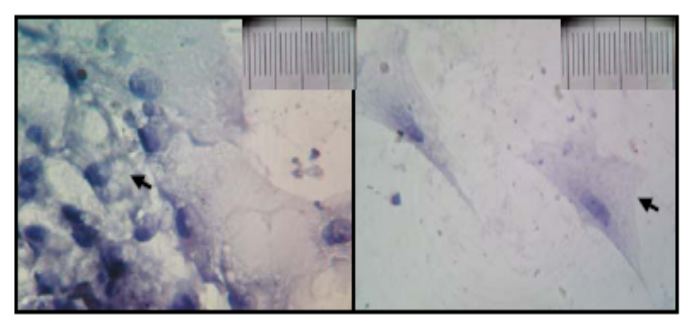

(A)

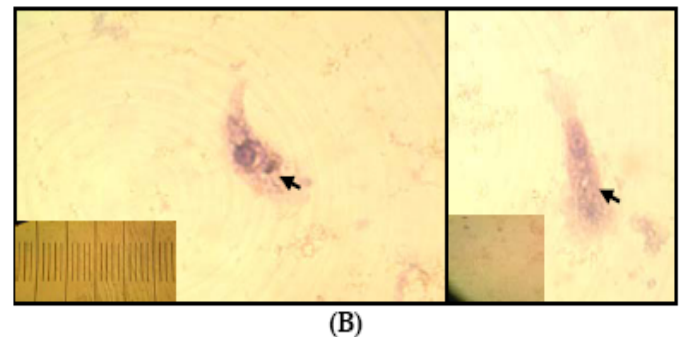

Gambar 6 Hasil imunositokimia menggunakan Anti Mouse TNF-a pada kultur sel trofoblas (Diamati pada mikroskop cahaya dengan perbesaran 400X) (A) tanpa glukosa $33 \mathrm{mM}$ (B) dengan glukosa $33 \mathrm{mM}$ KETERANGAN : 1 Bar $=0,1$ ìm

Berdasarkan hasil perhitungan ekspresi TNF-a melalui analisis deskriptif didapatkan rata-rata jumlah sel yang mengekspresikan TNF-a seperti tercantum pada Tabel 2 .

Hasil perhitungan rerata persentase ekspresi TNF-a pada sel trofoblas yang dipengaruhi oleh paparan glukosa dan perlakuan polifenol teh hijau selama 3 hari dapat dilihat pada Gambar 7. 
Tabel 2. Rerata Persentase Ekspresi TNF-a pada Kultur Sel Trofoblas dengan

Imunositokimia

\begin{tabular}{|c|c|c|}
\hline $\begin{array}{c}\text { Konsentrasi } \\
\text { polifenol } \\
\text { teh hijau } \\
(\mathrm{mg} / \mathrm{ml})\end{array}$ & \multicolumn{2}{|c|}{ Persentase ekspresi TNF- $\alpha(\%)$} \\
\cline { 2 - 3 } & Glucosa Normal & Paparan glukosa 33 mM \\
\hline 0 & 0 & 3 \\
\hline 0,1 & 0 & 82 \\
\hline 0,2 & 2 & 0 \\
\hline 0,4 & 5,5 & 0 \\
\hline
\end{tabular}

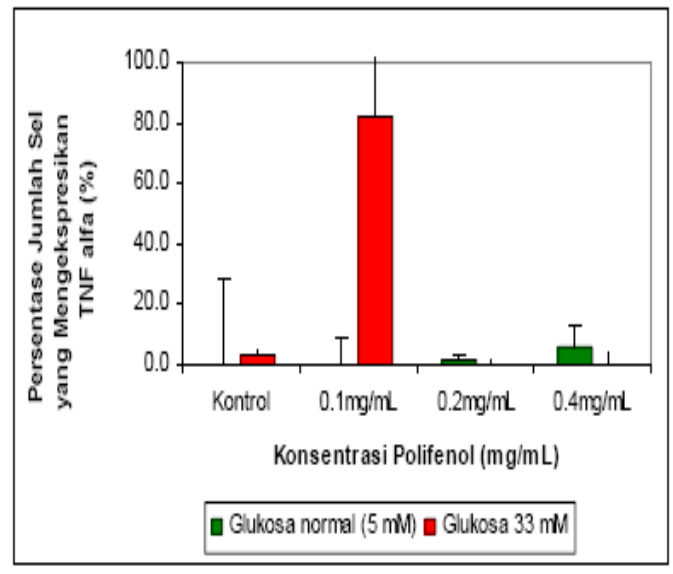

Gambar 7. Rerata Konsentrasi Polifenol Teh Hijau pada Kultur Sel Trofoblas Normal dan Dipapar Glukosa 33 $\mathrm{mM}$ selama 3 hari terhadap Jumlah Sel yang Mengekspresikan TNF-a dengan Imunositokimia

Hasil perhitungan menunjukkan bahwa ekspresi TNF-a meningkat pada kultur sel trofoblas yang dipapar glukosa tinggi (3\%) dibandingkan dengan kontrol negatif $(0 \%)$. Pada perlakuan tanpa pemaparan glukosa $33 \mathrm{mM}(0 \%)$ tidak terjadi perubahan ekspresi TNF-a pada konsentrasi polifenol $0,1(0 \%)$. Sedangkan pada konsentrasi 0,2 dan $0,4 \mathrm{mg} / \mathrm{mL}$ terdapat peningkatan ekspresi TNF-a berturut-rurut sebesar ( $2 \%$ dan 5,5\%) dibandingkan dengan kontrol negatif $(0 \%)$. Pada perlakuan polifenol $0,1 \mathrm{mg} / \mathrm{mL}$ yang dipapar glukosa tinggi terdapat peningkatan ekspresi TNF-a ( $82 \%$ ) dibandingkan dengan kontrol positif (tanpa pemaparan polifenol). Hal ini menunjukkan bahwa pada dosis polifenol $0,1 \mathrm{mg} / \mathrm{mL}$ belum mampu menurunkan ekspresi TNF-a pada kultur sel trofoblas sedangkan pada konsentrasi polifenol 0,2 dan $0,4 \mathrm{mg} / \mathrm{mL}$ terdapat penurunan ekspresi TNF-a (0\%) dibandingkan dengan kontrol positif $(3 \%)$. Hal ini menunjukkan bahwa konsentrasi 0,2 dan 0,4 mg/mL mampu menurunkan ekspresi TNF-a.

Penelitian tentang polifenol teh hijau menunjukkan adanya potensi antioksidan dari bahan-bahan yang terkandung di dalamnya yang mempunyai kemampuan radical scavenging. Komponenkomponen yang dikandung oleh polifenol tersebut mempunyai kemampuan $\mathrm{OH}$ radical scavenging yang efektif pada peroksidasi lipid nonenzimatis dan degradasi deoxyribose. Menurut Yang, et al., (1998), EGCG merupakan salah satu bahan alam yang diperoleh dari teh hijau yang salah satu mekanisme kerjanya adalah inhibisi aktivasi NF-kB. EGCG mampu menurunkan produksi TNF-á yang diinduksi LPS pada macrophage cell line RAW246.7 dan makrofag peritoneal dengan memblokir aktivasi NF-kB. Hasil yang didapatkan melalui imunositokimia berbeda dengan hasil yang didapatkan pada perhitungan ELISA bahwa meskipun terjadi peningkatan persentase jumlah sel yang mengekspresikan TNF-a pada sel trofoblas yang dipapar glukosa $33 \mathrm{mM}$, namun kadar TNF-a yang dihasilkan mengalami penurunan. Demikian halnya pada perlakuan polifenol, persentase jumlah sel yang mengekspresikan TNF-a hasil imunositokimia berbeda dengan hasil pengukuran kadar TNF-a melalui ELISA. Adanya resultanse data yang tidak signifikan pada penelitian ini, baik nilai kadar TNF-a maupun persentase jumlah sel yang mengekspresikan TNF-a diamsumsikan terkait dengan beberapa alasan, antara lain teknik isolasi sel trofoblas yang dilakukan secara mekanik sehingga diperoleh jenis sel dan jumlah populasi sel yang tidak homogen. Jadi kemungkinan sel masih belum murni dan populasinya bersifat heterogen. Resultanse data tersebut menyebabkan hasil dari penelitian ini belum mampu mendukung hipotesis bahwa polifenol teh hijau mampu menurunkan kadar TNF-á dan jumlah sel yang mengekspresikan TNF-á pada kultur sel trofoblas yang dipapar glukosa tinggi $33 \mathrm{mM}$ yang terkait dengan aktivasi NF-kB. Pada penelitian sebelumnya yang dilakukan oleh Lin, et al., (2002) selain berperan dalam patogenesis GDM, peningkatan TNF-a pada serum wanita hamil juga menunjukkan implikasi terhadap patogenesis Fetal Growth Restriction (FGR), premature rupture of membranes, preterm labor dan disfungsi endotel pada preeklampsia. 
Menurut Kirwan, et al., (2002), TNF-a merupakan predictor signifikan terhadap resistansi insulin selama kehamilan. TNF-á diproduksi oleh trofoblas yang berperan dalam pertumbuhan dan invasi trofoblas selama awal masa kehamilan. Namun, terjadinya peningkatan produksi TNF-á berperan pada kondisi patologis kehamilan, misalnya terdapat peningkatan konsentrasi TNF-á pada cairan amnion pasien preeklampsia menunjukkan bahwa sitokin TNF-á berperan dalam patofisiologi preeklampsia. Munculnya sitokin proinflamatori terkait dengan kejadian seluler yang menentukan dan memelihara kehamilan, namun perannya secara spesifik masih belum diketahui dengan jelas. Pada wanita hamil yang normal, TNF-á diduga memodulasi pertumbuhan dan invasi trofoblas pada arteri spiral maternal. Namun, TNF-á juga dapat berperan pada invasi plasenta abnormal, kerusakan sel endotel, dan oksidatif stres. Beberapa penelitian melaporkan bahwa konsentrasi TNF-á pada serum mengalami peningkatan secara signifikan pada

trimester pertama dan kedua di antara wanita hamil yang sesudahnya berkembang menjadi preeklampsia dibandingkan dengan kelompok kontrol.

\section{Kesimpulan}

Perlakuan polifenol teh hijau selama 3 hari pada konsentrasi $0,1 \mathrm{mg} / \mathrm{ml} ; 0,2 \mathrm{mg} / \mathrm{ml}$ dan $0,4 \mathrm{mg} / \mathrm{ml}$ sebagai antioksidan eksogen pada kultur sel trofoblas yang dipapar glukosa tinggi $33 \mathrm{mM}$ tidak mempengaruhi penurunan produksi TNF-á secara signifikan.

\section{Saran}

1. Perlu dilakukan isolasi sel trofoblas secara enzimatis agar didapatkan populasi sel yang homogen dan kepadatan sel yang terkontrol.

2. Perlu dilakukan observasi lebih lanjut tentang kisaran dosispolifenol teh hijau yang digunakan dalam pemaparan sel trofoblas

3. Perlu dilakukan perubahan waktu perlakuan yang dibutuhkan untuk mengetahui perubahan kadar TNF-á, yaitu antara 6-24 jam setelah perlakuan karena pada waktu tersebut terjadi respon berupa produksi TNF-á yang optimal

\section{Daftar Pustaka}

Afshari, T. J., Ghomian, N., Shameli, A., Shakeri, M. T., Fahmidehkar, A. M., Mahajer, E., Khoshnavaz, R. dan Emadzadeh, M. 2005. Determination of Interleukin-6 and Tumor Necrosis Factor-Alpha Concentrations in Iranian-Khorasanian Patients with Preeclampsia. http://www.pub edcentral.nih.gov/articleren der.fcgi?artid $=1298308$

Ahmad, N., Gupta, S. dan Mukhtar, H. 2000. Green Tea Polyphenol Epigallotechin-3-Gallate Differentially Modulates NF-kB in Cancer Cells Versus Normal Cells. Arch Biocheem Biophysics 2000;376:338346

Ann dan Zigang, 2003. Signal Transduction Pathways: Targets for Green Tea and Black Tea Polyphenols. Journal of Biochemistry and Molecular Biology. Vol. 36, No. 1, January 2003, pp. 66-77

Anizan. 2002. Imunohistokimia. http:// www.angelfire.com/gundam/ anizan.projekimunohistokimia. html

Anonimus. 2006. Peranan Antioksidan pada Penyakit-Penyakit Degeneratif http:/ / w w w. g a l e n i u m. c o m/ News.aspx?ArtID=24\&id=detail\&article=detail

Anonymous. 2008. Glucose Transport Proteins. http://www.med bio.info/ $\mathrm{H}$ or n / T i m e \% $203-/$ glucose_transport_pro teins.htm

Atègbo, J. M., Grissa, O., Yessoufou1, A., Hichami1, A., Dramane, K. L., Moutairou , K., Miled, K., Grissa, A., Jerbi6, M., Tabka, Z. dan Khan, N. A. 2006. Do Adiponectin, TNFá, leptin dan CRP Relate to Insulin Resistance in Pregnancy? Studies in Women with and without Gestational Diabetes, during and after Pregnancy. http:// www.pubmedcentral.nih. gov/ articlerender.fcgi?artid=1762494. 2005, SBDR-Society for Biomedical Diabetes Research

Barveni. 2003. Histologi. http:// www.lf3.cuni.cz/ustavy/histologie/ Atlas/barveni.en.php?barveni $=14$

Bischof, P dan Campana, A. 2007. Tropho- 
blast Differentiation dan Invasion: A Lesson to be Gained for Understdaning Implantation of The Human Embryo. Department of Obstetrics and Gynecology Geneva University Hospital

Black, S., Kadyrov, M., Kaufmann, P., Ugele, B. Emans, N. dan Huppertz, B. 2003. Syncytial Fusion of Human Trophoblast Depends on Caspase 8. Nature Jounal. Cell Death and Differentiation 11:90-98

Buren, 2002; Katzung, 2001 dalam Samsuri, 2005. Mekanisme Molekuler dari Penghambat Enzim Pengubah Angiotensin dalam Memperbaiki Resistensi Insulin yang Diinduksi

Glukokortikoid. Jurnal Veteriner Fakultas Kedokteran Hewan Universitas Udayana. Jvet Vol 6(2) 2005

Burgess, W. G. 1995. Teknologi ELISA dalam Diagnosis dan Penelitian. Gadjah Mada University Press. Yogyakarta

Collins, T. dan Cybulsky, M. 2001. NFkB:Pivotal Mediator or Innocent Bystdaner in Atherogenesis? J Clin Invest. 107:255-256

Coughland, M. T., Michael, P., Harry, M. G. dan Gregory, E. R. 2004. Repression of Oxidant-Induced Nuclear FactorB Activity Mediates Placental Cytokine Responses in Gestational Diabetes. The Journal of Clinical Endocrinology and Metabolism. 89(7):3585-3594.

Coughldan, M. T. K., Oliva, H. M., Georgiou, J. M. H., Permezel, G. E. dan Rice. 2001. Glucose-Induced Release of Tumor Necrosis Factor-Alpha from Human Placental and Adipose Tissues in Gestational Diabetes Mellitus. http://www.black wellsynergy.com/doi/abs/10.1046/ j.1464-5491.2001.00614.?cookie Set $=1 \&$ journalCode $=$ dme

Chen, H. L., YP Yang., XL Hu., Yelavarthi, K. K., Fishback, J. L. dan Hunt, J. S. 1991. Tumor Necrosis Factor Alpha mRNA and Protein are Present in Human Placental and Uterine Cells at Early and Late Stages of Gestation

Dabbs, D. 2006. Diagnostic Immunohistochemistry. 2nd Edition. Elsevier
Inc. New York

Davidson. 2000. TNF-Alpha. http:// www.bio.davidson.edu/COUR SES/ Immunology/Students/spring2000/ wolf/tnfalpha.html

Desoye, G. dan Hauguel-de Mouzon, S. 2007. The Human Placenta in Gestational Diabetes Mellitus. http:// care.diabetesjournals.org/cgi/ content/full/30/Supplement_2/S120/F2

Haddad, J.J. 2002. Oxygen homeostasis, Thiol Equilibrium and Redox Redox Regulation of Signalling Transcription Factors in The Alveolar Epithelium. Cell Signal 14: 799-810

Hahn, T., S. Barth, U. Weiss, W. Mosgoeller, dan G. Desoye. 1998. Sustained Hyperglycemia In Vitro DownRegulates The Glut1 Glucose Transport System Of Cultured Human Term Placental Trophoblast: A Mechanism To Protect Fetal Development? The Faseb Journal Vol. 12 : 1221-1231

Halliwel, B. dan Gutteridge, J. M. C. 1998. Free Radical and Antioxidant in Human Disease in Analysis of Free Radicals. In Biological System. Berlin

Iwahasi, H. 1998. Mollecular Mechanism of Pancreatic Beta Cell Destruction in Autoimmune Disease : Potential Target For Preventive Therapy, Cytokines, Cellular and Mollecular Therapy 94: 45-51

Jakus, V. 2000. The Role of Free Radical, Oxidative Stress and Antioxidant System in Diabetic Vascularr Disease. Bratisl. Lek. Listy. 101:541-551

Jansson, T., Wennergren, M. dan Illsley, N. P. 1993. Glucose Transporter Protein Expression In Human Placenta Throughout Gestation And In Intrauterine Growth Retardation. Journal of Clinical Endocrinology \& Metabolism, Vol 77, 1554-1562

Jones, V. 1996. Methods in Molecular Medicine, Human Cell Culture Protocols. King's College University of London. Humana Press. UK

Junquiera, C. L., Carneiro, J. dan Kelley, O. R (Tambayong, J). 1998. Edisi ke8. Penerbit Buku Kedokteran EGC. Jakarta

Keman, K. 2005. Hubungan antara IL-10 dan IFN-ã pada jaringan Trofoblas dan 
Sel Sitotrofoblas dengan Kegagalan Proses Diferensiasi, Invasi, dan Pseudovaskulogenesis Trofoblas pada Patogenesis Preeklampsia. Disertasi Program Doktor Ilmu Kedokteran. Universitas Brawijaya. Malang

Khotimah, H. 2003. Pengaruh Vitamin E dan Vitamin C terhadap Release Endothelia Derived Relaxing factor (EDRF), KadarMDA dan Kepadatan Sel Endotel HUVECs yang Dipapar Glukosa Tinggi. Tesis. Program Studi Biomedik. Program Pascasarjana. Universitas Brawijaya. Malang

Kirwan, P. J., Sylvie Hauguel-De Mouzon., Lepercq, J., Jean-Claude Challier., Larraine Huston-Presley,. Friedman, E. J. Kalhan, C. S. dan Catalano, M. P. 2002. TNF-á Is a Predictor of Insulin Resistance in Human Pregnancy

Kliman, H. J. 1998. From Trophoblast to Human Placenta (From The Encyclopedia of Reproduction). Yale University School of Medicine

Kumalaningsih, S. 2007. Antioksidan Alami Penangkal radikal bebas. Sumber, Manfaat, Cara Penyediaan dan Pengolahan.

Trubus Agrisarana. Surabaya. Halaman 7577

Lappas, M., Permezel, M., dan Rice, G.E. 2004. Release of Proinflammatory Cytokines dan 8-Isoprostane from Placenta, Adipose Tissue, and Skeletal Muscle from Normal Pregnant Women dan Women with Gestational Diabetes Mellitus. The Journal of Clinical Endocrinology \& Metabolism 89(11):5627-5633

Lautan, J. 1997. Radikal Bebas pada Eritrosit dan Leukosit. Cermin Dunia Kedokteran. No. 116.

Lin, Y. L. dan Lin J. K. 1997. Epigallocatechin-3-Gallate Blocks the Induction of nitric Oxide Synthase by Down Regulating Lipopolysaccharide-Induce Activity of Transcription FactorNuclear Factor kB. Mol Pharmacol. 52:465-472.

McKay, D. dan Blumberg, J. 2002. The Role of Tea in Human health. J. Am Coll Nutr. 2002;21:1-13
Megia, A., Gallart, L., Jose-Manuel Fernández-Real, L, Vendrell, J.,

Simón, I., Gutierrez, C. dan Richart, C. 2004. Mannose- Binding Lectin Gene Polymorphisms Are Associated with Gestational Diabetes Mellitus. http:/ /jcem.endojournals.org/ cgi/content/ full/89/10/5081 ?ck=nck

Nusindrati, 2003. Efek N-Asetilsistein terhadap kadar MDA dan Hidrogen Peroksida pada kultur sel Endotel yang dipapar Glukosa Tinggi (22mM). Tesis. Program Studi Biomedik. Program Pascasarjana. Universitas Brawijaya. Malang

Pincemail, J. 1995. Free Radical dan Antioxidant in Human Disease in Analysis of Free Radicals in Biological System. Berlin

Reksoprodjo, M. dan Wibowo, N. 1999. Reksoprodjo dan Wibowo, 1999. Gametogenesis, Fertilisasi dan Implantasi. library.usu.ac.id/ download/fk/obstetri-letta.pdf -

Rice-Evans, C.A, N.J. Miller, G. Paganga. 1997. Antioxidant properties of phenolic compounds. Trends in Plant Science 2:152-159

Roitt, I. M. dan P. J. Pelves. 2001. Essential of Immunology, $10^{\text {th }}$ Editions. Blackwell Science, Ltd. London

Rosen, T., Krikun, G., Yuehong Ma, Wang, En-Yu, Lockwood, C. J. dan Guller, S. 1998. Chronic Antagonism of Nuclear FactorkB Activity in Cytotrophoblast by Dexamethasone: A Potential Mechanism for Antiinflamatory Avtoin of Glucocorticoids in Human Placenta, Journal of Clinical Endocrinology and Metabolism, 10:3647-3652

Samsuri, 2005. Mekanisme Molekuler dari Penghambat Enzim Pengubah Angiotensin dalam Memperbaiki Resistensi Insulin yang Diinduksi Glukokortikoid. Jurnal Veteriner Fakultas Kedokteran Hewan Universitas Udayana. Jvet Vol 6(2) 2005

Scott, B. 2006. "R\&D Systems" TNF-alpha Quantikine ELISA System. w w w . b i o com par e.com/ archive. asp? Vendorid $=364$.

Sianne. 2006. Penghambatan Aktivasi NFkB dan Ekspresi TNF-á oleh Polifenol Teh Hijau pada Kultur 
HUVECs yang Dipapar LDL Teroksidasi. Karya Akhir. Program Pendidikan Dokter Spesialis (PPDS) Ilmu Penyakit Dalam. Fakultas Kedokteran. Universitas Brawijaya. Malang

Sigma Aldrich. 2008. Attachment dan Matrix Factors. http:// www.sigmaaldrich.com/ Area_of_Interest/Life_Science/ Cell_Culture/Product_Lines/ Reagents___Supplements/Attach ment_Factors.html

Suparman, E. 2003. Malaria pada Kehamilan. Cermin Dunia Kedokteran Ginekologi No. 146:2.

Torchinsky, A. dan Toder, V. 2007. TNF-alpha in The Pathogenesis of Diabe-

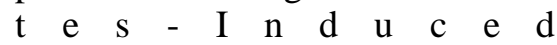
Embryopathies:Function dan $\mathrm{T}$ a $\mathrm{r} g$ e $\mathrm{t} \mathrm{s}$. h t $\mathrm{t} \mathrm{p}: / /$ www.ncbi.nlm.nih.gov/pubmed/ 18338073 ? ordinalpos

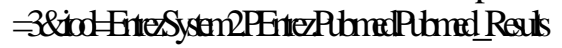
Panel.Pubmed_RVDocSum

Tuminah, S. 2000. Radikal Bebas dan Anti Oksidan- Kaitannya dengan Nutrisi dan Penyakit Kronis. Pusat Penelitian Penyakit Tidak Menular, Badan Penelitian dan Pengembangan Kesehatan, Departemen Kesehatan RI, Jakarta. Cermin Dunia Kedokteran No. 128. 11.

Wertheimer, E., Sasson, S., Cerasi, E. dan Ben-Neriah, Y. 1991. TheUbiquitous Glucose Transporter GLUT-1 Belongs To The Glucose-Regulated Protein Family Of Stress-Inducible Proteins. Proc Natl Acad Sci USA. March 15; 88(6): 2525- 2529

Wan Ho, M. 2007. Green Tea, The Elexir of Life? www.maydayinfo. dk/ 715.0.html

Wolf., Myles, S., Knickerbocker., Lynn, T., MacBeath., Gavin. Dan Ravi, T. 2002. Screening for gestational disorders. http:// www. freepatents online.com/ 20050148023.html

Wurandari, A. 2002. Pengaruh Kadar Glukosa Tinggi Terhadap Perubahan Struktur (Apoptosis) dan Profil Superoksid O2 dan Superoksid Dismutase (SOD) pada Kultur Hu- man Umbilical Vein Endoyhelial Cells (HUVECs). Tesis Program Pascasarjana Ilmu Kedokteran. Universitas Brawijaya. Malang

Yang, F., de Villiers, W. J. S., Willem, J. S., Mc. Clain, C. J. 1998. Green Tea Polyphenols Block Endotoxin-Induced TNF-á Production dan Lethality in A Murine Model. J.Nutr; $128: 2334-2340$

Yatim, W. 1994. Reproduksi dan Embriologi. Penerbit Tarsito. Bandung

Zhao, L. 2001. Effects of Free Radical in Diabetes. Free Radical in Biology dan Medicine. Department of Radiology B-180 ML. The University of Iowa. Iowa City 